\section{Detection and Molecular Characterization of Infectious Laryngotracheitis Virus in Laying Hens in Brazil}

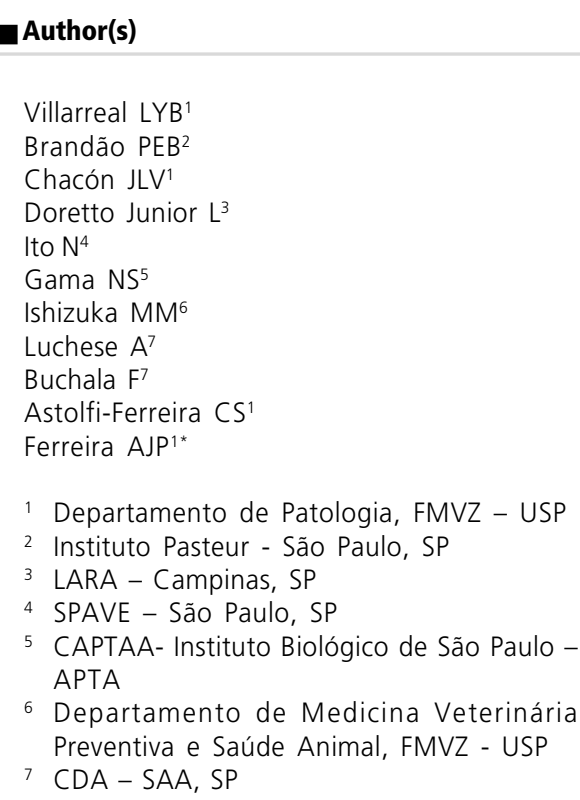

Mail Address

Antônio José Piantino Ferreira Departamento de Patologia Faculdade de Medicina Veterinária e Zootecnia Universidade de São Paulo. Av. Prof. Dr Orlando Marques de Paiva, 87 Cidade Universitária - Butantã 05.508-900 - São Paulo, SP, Brasil

E-mail: ajpferr@usp.br

\section{Keywords}

Avian infectious laryngotracheitis, Brazil, p32, $P C R$, sequencing.

\section{ABSTRACT}

Avian Infectious Laryngotracheitis, caused by Infectious Laryngotracheitis Virus (ILTV), has been reported for decades in Brazilian laying and broiler flocks. More recently, outbreaks have occurred in São Paulo State. This study reports the application of PCR and DNA sequencing targeted to the p32 gene of ILTV using laying chicken samples from Bastos, São Paulo, Brazil. Three out of four field samples were positive by PCR. DNA sequencing of two samples evidenced homology of the amplified fragments with the p32 gene of ILTV. The results definitely confirmed the presence of ILTV in the birds during the outbreak. Further studies are needed to establish the sources of infection and to determine whether the detected virus was originated from vaccine or field virus strains.

\section{INTRODUCTION}

Avian Infectious Laryngotracheitis Virus (ILTV) is the common name of the Gallid herpesvirus 1 species, classified in the family Herpesviridae, subfamily Alphaherpesvirinae, genus I/tovirus, which genome is a linear double-stranded DNA with 32 kb (Johnson \& Tyack, 1995).

The term infectious laryngotracheitis comes from the clinical symptoms caused by ILTV, such as dyspnea, coughing with expectoration of blood-stained mucus and nasal discharge, decreased egg production, conjunctivitis and sinusal swelling (Bagust \& Guy, 1997).

Major gross lesions observed in affected birds are inflammatory processes in the trachea and larynx, which might vary from hemorrhagic to mucoid. Diphtheritic lesions with mucoid or hemorrhagic membranes and necrotic tissue may be seen along the trachea and may spread to the inferior respiratory tract. ILTV disseminates from bird to bird by aerogenic route and via fomites until virtually all birds are affected; egg transmission has not been reported yet (Davidson et al., 1988; Linares et al., 1994; Bagust \& Guy, 1997).

As a herpesvirus, ILTV is expected to become latent in some tissues of an infected bird as circular DNA in the cytoplasm or by integrating its DNA to the genomic DNA of the host cell. This is true not only in field strains but also in vaccine strains, with implications to the clearance of the virus from the infected birds and in the control of the disease on poultry flocks (Bagust \& Johnson, 1995).

The improvement of simple and objective diagnostic techniques such as the Polymerase Chain Reaction (PCR) and DNA sequencing is required to confirm ILTV infections when the disease is clinically suspected and situations in which no disease is suspected, such as latent infections.

The first report of infectious laryngotracheitis in Brazil dates from 1974 and since then many cases were reported based on serological, 
Villarreal LYB, Brandão PEB, Chacón JLV, Doretto L, Ito N, Gama NS, Ishizuka MM, Luchese A, Buchala F, Astolfi-Ferreira CS, Ferreira AJP

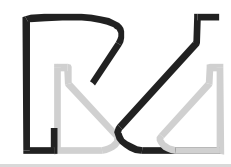

Detection and Molecular Characterization of Infectious Laryngotracheitis Virus in Laying Hens in Brazil virological and histopathological tests (Hipólito et al., 1974; Vargas, 1995; Beltrão et al, 2002; Ito et al, 2003; Gama, 2004).

This article reports the detection of ILTV by PCR and DNA sequencing targeted to the 032 gene in samples collected from an outbreak of infectious laryngotracheitis in laying hens in Brazil.

\section{MATERIALS AND METHODS}

\section{History}

Four suspicious virus isolates that induced characteristic ILTV-lesions in the chorioallantoic membrane (CAM) of embryonated eggs were sent to the Laboratory of Ornitopathology from University of São Paulo by Ministério da Agricultura, Pecuária e Abastecimento (MAPA) and Laboratório Regional de Apoio Animal (LARA) in order to confirm and characterize ILTV.

The isolates originated from samples collected during an outbreak in Bastos, São Paulo, in 2002; the samples were stored at $-80^{\circ} \mathrm{C}$ prior to the tests.

\section{Polymerase Chain Reaction (PCR) Primers}

The pair of primers described by Vögtlin et a/(1999) was used in the PCR (Table 1). These primers targeted the p32 gene of ILTV and produced a 588-bp fragment.

\begin{tabular}{ll}
\hline Table1 - Primers used to amplify the p32 gene of ILTV. \\
\begin{tabular}{cl} 
Primer & Sequence \\
ILTU2 & 5' CTACGTGCTGGGCTCTAATCC 3' \\
ILTL2 & 5'AAACTCTCGGGTGGCTACTGC 3' \\
\hline
\end{tabular}
\end{tabular}

\section{DNA extraction}

DNA was extracted according to Chomczinsky (1993) and was stored at $-80^{\circ} \mathrm{C}$ until analysis.

The positive control was allantoic fluid of SPF chicken embryos inoculated with a ILTV reference strain from MAPA and the negative control was PBS $0.01 \mathrm{M}$, $\mathrm{pH} 7.2$

\section{Amplification}

Five microliters of the extracted DNA were added to the PCR mix (1 x PCR Buffer ${ }^{\mathrm{TM}}$ (Invitrogen ${ }^{\mathrm{TM}}$ ), $0.2 \mathrm{mM}$ of each dNTP, $0.5 \mathrm{pmol} / \mu \mathrm{L}$ of each primer (ILTU2 and ILTL2), $1.5 \mathrm{mM} \mathrm{MgCl} 2,25.25 \mu \mathrm{L}$ of ultra-pure water and 1.25U Taq DNA polymerase to a final reaction of $50 \mu \mathrm{L}$ ).
The reaction was carried out in a Biometra ${ }^{\mathrm{TM}}$ termocycler, with a initial denaturation at $95^{\circ} \mathrm{C}$ for 5 minutes, followed by 35 cycles at $95^{\circ} \mathrm{C}$ for $1 \mathrm{~min}, 55^{\circ} \mathrm{C}$ for $1.5 \mathrm{~min}, 72^{\circ} \mathrm{C}$ for $2 \mathrm{~min}$, and a final extension at $72^{\circ} \mathrm{C}$ for $10 \mathrm{~min}$.

Ten microliters of the PCR product were analyzed by electrophoresis in $1.5 \%$ agarose gel, stained with $0.5 \mathrm{mg} / \mathrm{mL}$ ethidium bromide and observed under UV light for visualization of the 588-bp fragment.

\section{DNA sequencing}

The PCR products (588 bp) from two samples were submitted to DNA sequencing to confirm the specificity of the amplicons.

The sequencing reaction contained $4 \mathrm{~mL}$ of BigDye 3 (Applied Biosystems ${ }^{\circledR}$ ), $4 \mathrm{~mL}$ of $5 \times$ Sequencing Buffer (Applied Biosystems ${ }^{\circledR}$ ), 4 pmol of each primer ILTU2 and ILTL2 and $10 \mathrm{ng}$ of target DNA. Product sequences were resolved on an ABI-310 automatic sequencer (Applied Biosystems ${ }^{\circledR}$ ).

Sequence homology of ILTV was evaluated by alignment and comparison with sequences from GenBank using BLASTn (www.ncbi.nlm.nih.gov/BLAST).

\section{RESULTS}

\section{Polymerase Chain Reaction (PCR)}

As shown in Figure 1, the expected fragment of $588 \mathrm{bp}$ of the p32 gene of ILTV was obtained in three out of four samples, as well as in the reference strain used as positive control; no bands were detected in the negative control.

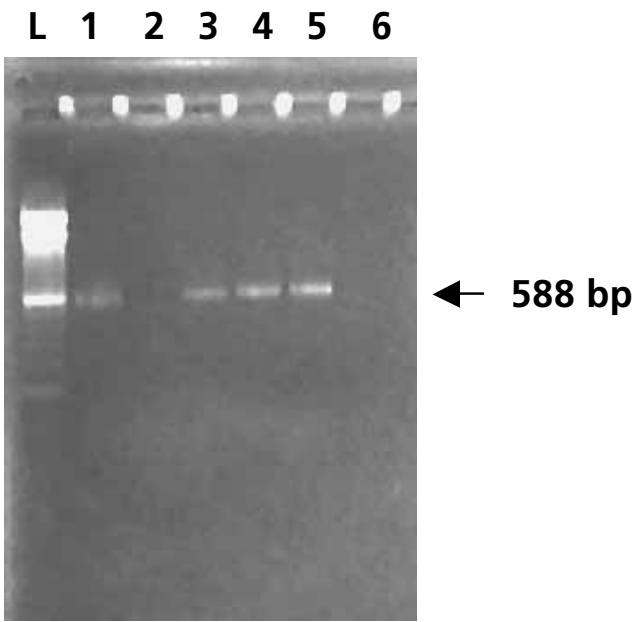

Figure 1 - Visualization of the 588-bp PCR product from the p32 gene of ILTV by agarose gel electrophoresis (1.5\%) after staining with ethidium bromide. $L=100-b p$ DNA ladder; 1-4= field strains isolated in CAM; $5=$ positive control (ILTV reference strain); $6=$ negative control (PBS $0.01 \mathrm{M}, \mathrm{pH} 7.2$ ). 
Villarreal LYB, Brandão PEB, Chacón

JLV, Doretto L, Ito N, Gama NS, Ishizuka MM, Luchese A, Buchala F, Astolfi-Ferreira CS, Ferreira AJP

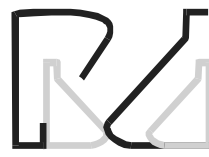

Detection and Molecular Characterization of Infectious Laryngotracheitis Virus in Laying Hens in Brazil

\section{DNA sequencing}

The amplicons of the two positive samples showed sequences with 534 and 518 nucleotides (nucleotide identity of $99 \%$ ). BLASTn retrieved only sequences from ILTV (mean nucleotide identities of $99.2 \%$ and $98.4 \%$ to samples 01 and 02 respectively), and no other sequences showed significant scores (Figure 2).

The sequences of 132 gene were deposited in the GenBank under the accesion numbers AY598339 and AY541676.

\section{DISCUSSION}

Four samples of CAM collected from chicken embryo eggs inoculated with Infectious Laryngotracheitissuspected tissues from laying chickens were analyzed by PCR and three showed positive results to ILTV. The specificity of the PCR product was confirmed when two of these were submitted to DNA sequencing.
The positive results in the PCR directed to the p32 gene of ILTV is in agreement with the characteristic symptoms of laryngotracheitis observed in the surveyed birds, as tracheitis, watery eyes and dyspnea.

Thus, the PCR described in the present study is a useful tool to confirm the diagnosis of birds suspected of infectious laryngotracheitis. Results can be obtained in less than 24 hours, which is an essential point in outbreaks, when fast decisions are required.

The application of the procedures described herein must be evaluated for field strains collected from suspected birds prior to the inoculation in embryonated eggs, considering that PCR applied to viral diagnosis is a highly sensitive technique (Forghani \& Erdman, 1994) that allows the detection of infection in a very early phase when compare to serological reactions (Pang et al., 2002).

Besides, as shown by sequencing of the PCR products of two samples, the primers and amplification

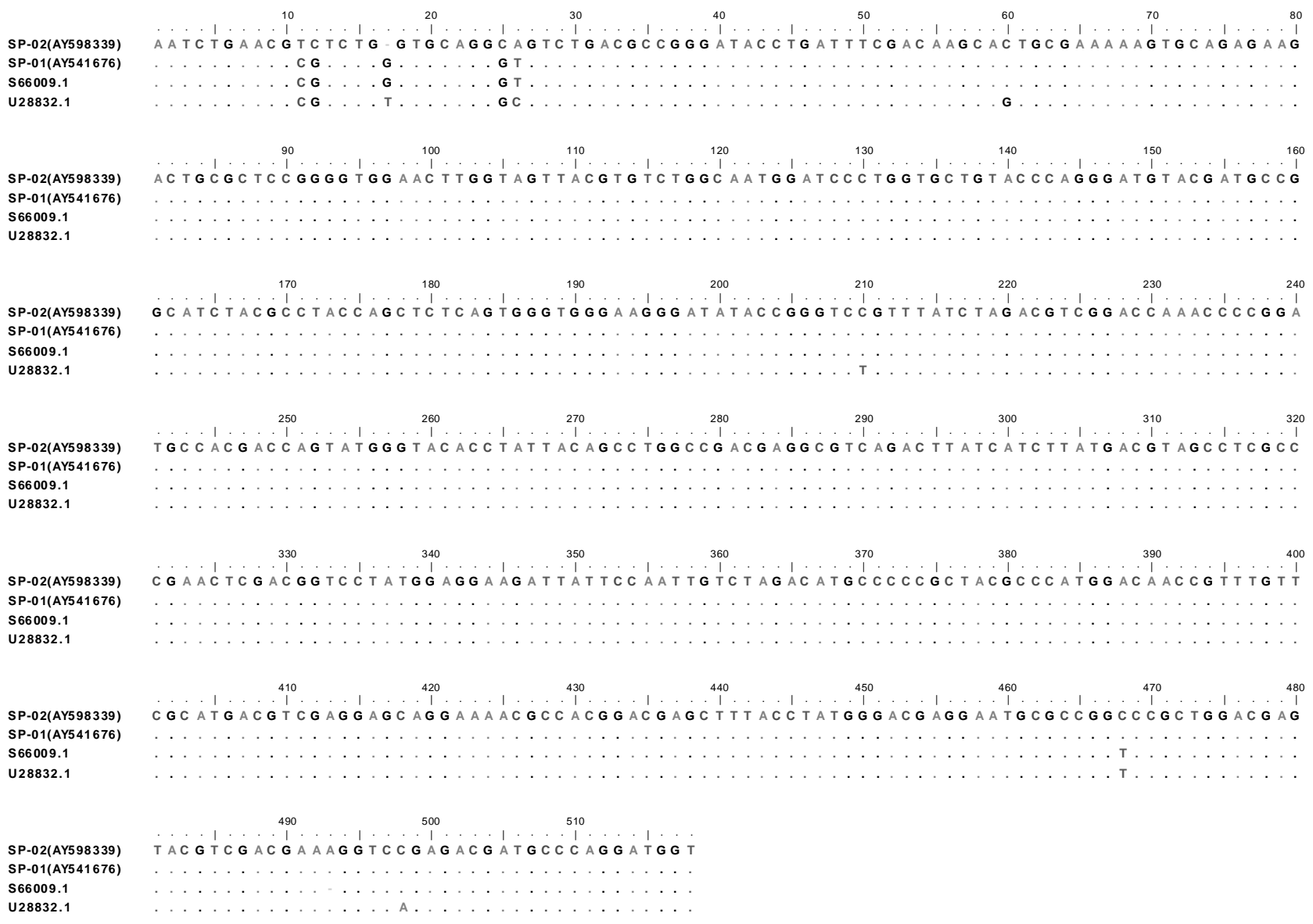

Figure $\mathbf{2}$ - Nucleotide alignment of a region of the p32 gene of ILTV. Samples SP-01 and SP-02 belong to the study reported herein and the other two sequences were retrieved from GenBank. 
Villarreal LYB, Brandão PEB, Chacón

JLV, Doretto L, Ito N, Gama NS,

Ishizuka MM, Luchese A, Buchala

F, Astolfi-Ferreira CS, Ferreira AJP
Detection and Molecular Characterization of Infectious Laryngotracheitis Virus in Laying Hens in Brazil conditions described here allow a specific and safe diagnosis when applied to ILTV strains present in Brazilian poultry farms. The DNA sequencing technique can be applied to the identification of field and vaccine strains, since some available molecular markers permit such differentiation (Chang et al., 1997).

These results definitely confirm the presence of ILTV in the Infectious Laryngotracheitis outbreak in the region of Bastos, São Paulo State. Nevertheless, it is necessary to establish a continuous epidemiological surveillance in this region to determine the incidence, prevalence and economic impact of the disease, using conventional methods such as isolation in embryonated eggs and also the PCR described herein.

Furthermore, it is fundamental to identify the origin of the viruses detected in this outbreak, i.e., whether they are field or vaccine strains, in order to determine the source of infection and routes of transmission. The evaluation of the molecular diversity of field strains in the surveyed area, involving also other regions of the genome of the pathogen, might also contribute to the establishment of prophylactic and control measures.

\section{REFERENCES}

Bagust TJ, Guy JS. Laryngotracheitis. In: Calnek BW, editor. Diseases of poultry. $10^{\text {nd }}$ ed. Ames: lowa State University Press; 1997. p. $527-$ 539.

Bagust TJ, Johnson MA. Avian Infectious Laryngotracheitis: virushost interactions in relation to prospects for eradication. Avian Pathology 1995; 24:373-391.

Beltrão N, Leão JA, Rocha SLS, Furian TQ, Bianco AJ, Canal CW. Detection of Infectious Laryngotracheitis Virus form poultry by a nested-PCR. Journal of Brazilian Society for Virology 2002; 7:1134.

Chang $\mathrm{P}$, Lee $\mathrm{Y}$, Shien J, Shieh $\mathrm{H}$. Rapid differentiation of vaccine strains and field isolates of infectious Laryngotracheitis virus by restriction fragment length polymorphism of PCR products. Journal of Virological Methods 1997; 66:179-186.

Chomkczynski PA. A reagent for the single-step simultaneous isolation of RNA, DNA and protein from the cell and tissues samples. Biotechniques 1993; 15:532-537.

Davidson S, Eckroade R, Miller K. Laryngotracheitis - the Pennsylvania experience. In: Proceedings of the 23 National Meeting of Poultry Health Condemnations, 1988; Ocean City: MD; 1988. p. 14-9.

Forghani B, Erdman DD. Amplification and detection of viral nucleic acids. In: Schmidt JN, Emmons RW. Diagnostic procedures for viral, rickettsial and chlamydial infections. Washington, DC: American Public Health Association; 1994. p. 97-120.
Gama N. Laringotraqueite: o caso brasileiro. In: Conferencia APINCO 2004 de Ciência e Tecnologia Avícolas; 2004 maio 4 a 7; Santos; São Paulo. Brasil. Campinas: FACTA; 2004. p.85-92

Hipólito O, Soares LA, Pereira OAC, Pinto AA, Bottino JA. Isolamento e identificação do vírus da Laringotraqueite infecciosa das galinhas no Brasil. In: Congresso Brasileiro de Microbiologia; 1974; Rio de Janeiro, RJ. Brasil. p. 16.

Ito NMK, Gama NMSQ, Miyaji Cl, Okabayashi S, Lima EM, Babadopulos P. Diagnóstico da laringotraqueíte infecciosa das galinhas. Brazilian Journal of Poultry Science 2003; Suplemento 5:118.

Johnson MA, Tyack SG. Molecular evolution of infectious laryngotracheitis virus (ILTV: gallid herpesvirus 1): An ancient example of Alphaherpesviridae? Veterinary Microbiology 1995; 46:221-231.

Linares JA, Bickford AA, Cooper GL, Charlton BR, Woolcock PR. An outbreak of infectious laryngotracheitis in California broilers. Avian Diseases 1994; 38:188-192.

Pang $Y$, Wang H, Girshick T, Xie Z, Khan M. Development and application of a multiplex polymerase chain reaction for avian respiratory agents. Avian Diseases 2002; 46:691-699.

Vargas RES. Laringotraqueíte infecciosa das aves: Estudo epidemiológico em plantéis avícolas no Estado do Rio Grande do Sul. [Dissertação]. Porto Alegre (RS): Universidade Federal Rio Grande do Sul; 1995.

Vögtlin A, Bruckner L, Ottiger $\mathrm{H}$. Use of polymerase chain reaction $(P C R)$ for the detection of vaccine contamination by infectious Laryngotracheitis virus. Vaccine 1999; 17:2501-2505 